\title{
TCOM \\ Who doesn't love a good story? - What neuroscience tells about how we respond to narratives
}

\section{Craig Cormick}

\begin{abstract}
Can we really say what type of story has impact on us, and what type of story does not? Evidence suggests that we can. But we need to better understand the way that stories work on us, at a neural and empathetic level, and better understand the ways that the elements of stories, such as structure and metaphor work. By combining scientific research with the deeper wisdom of traditional storytelling we have both a deep knowledge married to scientific evidence - which can be very powerful tools for science communicators.
\end{abstract}

Keywords

DOI

In the beginning
Public engagement with science and technology; Representations of science and technology; Science writing

https://doi.org/10.22323/2.18050401

Submitted: 8th February 2019

Accepted: 18th March 2019

Published: 14th October 2019

Let me tell you a story...

Once upon a time there was a belief that spread across the land that the power of stories and narratives was so great that they could change the way people thought about things, and even their behaviours. This belief became so widespread that large corporations even started sending employees on storytelling workshops, talking about their 'Corporate Story', or even employing people as 'Corporate Storytellers' — with that title boldly stated on their business cards.

Communications in the public and private sectors were all about getting the 'narrative right', and having a 'significant story' to tell. Suddenly everyone was talking story. The only problem was that at the corporate and political level nobody really seemed to know what a story or a narrative actually was - nor how they really worked in influencing people's attitudes, beliefs or behaviours.

Certainly it had something to do with engaging people more deeply and capturing their imagination - but in practice it was too often about developing a better promotional slogan or a media release angle. 
That is a pity as this will invariably lead to some diminished trust in storytelling, dismissing it as just the latest corporate-think buzzword that didn't live up to its grand hype. It will be filed away next to Innovation and Triple-bottom line and Service-orientation, to gather dust until its turn to be rediscovered eventually comes around again.

It is worth pointing out here that there is a common tendency to use narrative and stories interchangeably, though in truth they are a little different. Halverson [2011] describes this difference as: narratives are composed of multiple stories that relate to one another, while stories are a single "event unit".

But he also acknowledges that explaining the difference between a story and a narrative can easily get bogged down in academic jargon and "eyes will glaze over".

Regardless of your need to know the finer points of these definitions, it is more useful perhaps to know that the power of stories is real, and they can be used for great effect if we better understood exactly how they work on us, and how they don't.

Science communicators as story tellers
Science communicators, who often rely on the power of story in their daily efforts, have added significantly to our understanding of the impact of stories, through both research and practice. And when combined with the wisdom of those who study stories as they have evolved culturally over thousands of years - we have both a deep knowledge married to scientific evidence - which can be very powerful.

So what does science tell us about how stories work on us? A variety of studies have found that good narratives, or framing information in stories, has been shown to:

- Increase people's likelihood of remembering information [Graesser et al., 1980],

- Reduce counter-arguing [Green and Brock, 2000],

- Make people feel the experience being described was their own [Niemand, 2018],

- Be much more convincing than just data [Niemand, 2018],

- Increase engagement, when communicating science to non-expert audiences [Dahlstrom, 2014].

Stories do this by tapping into the parts of our brains that process information more efficiently when it is presented in a narrative format, especially when that information has social relevance [Downs, 2014].

U.S. Psychologist Uri Hasson and his colleagues [2010] tested the impacts of stories on our brains by having a woman tell a story while her brain was being scanned 
inside an fMRI machine. After mapping the areas where her brain lit up during the telling, they then scanned the brains of 11 volunteers who listened to a recording of the same story. They found that the listeners' brains lit up in similar ways during the story, and they were effectively experiencing the same brain stimulation as the teller.

Similarly, neuroscientist Mary Immordino-Yang [2011], from the University of Southern California, measured the brains of subjects while telling them a true story and found that they identified with the stories and characters on a visceral level — feeling strong waves of emotions.

A U.S. alternative sentencing program, Changing Lives Through Literature (CLTL), has turned such research into practice and found that well-told stories can actually re-orient the lives of adult offenders. The pilot program of CLTL included eight men who sat around a table with the University of Massachusetts professor Robert Waxler, and talked about different books that included Jack London's Sea-Wolf and James Dickey's Deliverance [Waxler and Trounstine, 1999].

Participants said they related strongly to the characters they read about and discussed, and found the motives and struggles of these characters helped them make better decisions in their own lives. In a study of 600 people who participated in the program, rates of criminal activity dropped by 60 per cent - compared to only 16 per cent of a control group.

Anyway you look at it — stories can strongly affect us.

So you can see why the corporate and political world has gotten so excited about stories, for their potential to get people to think in a way they might want them to think.

But the impacts of stories might be a little more subtle than that, and can't necessarily be used as a blunt tool for make people to think better of you, or to buy more of your product. If that were the case we'd be suckers for every new brand and political movement that came along with a new and compelling story. And we just aren't like that, are we.

Or are we? (At this point in the tale feel free to consider the impacts of the narratives behind President Trump's election, the Brexit strategy and every odd fashion trend from shoulder pads to jeans with more cut away from them than remains).

Impacts of good narratives
Of course not all stories achieve strong impacts with all people - and certainly not all science stories achieve the attitude and behaviour changes they'd like to achieve. But, let's be honest here, not all science stories are told well. As a science communicator I am too often left wondering why is it - if storytelling is the way we learn about life as children and how to make good judgments and better relate to each other - that when it comes to telling the stories of science so many people are so uniformly bad at it?

I suspect it is because the telling of stories is beaten out of so many of us, leaving us with tpp many efforts that are more what Sanford and Emmott [2013] refer to as 
'non-narratives' - collections of facts or descriptions with no strong sequence of events nor causal relationships.

Randy Olson [2015], former marine biologist and author of the best-selling book, Houston, We Have a Narrative, promotes the story-telling structure ABT (And, But, Therefore).

As an example of the ABT story structure he gives the following example:

I can tell you that in my laboratory we study physiology AND biochemistry, BUT in recent years we've realized the important questions are at the molecular level, THEREFORE we are now investigating the following molecular questions...

Another well-used story formula, that is often used by Hollywood is Freytag's Pyramid, after the $19^{\text {th }}$ Century German novelist and playwright, Gustav Freytag. It can be mapped across the rising and falling shape of a pyramid as Beginning, Rising problem, Climax, Cooldown, and Resolution.

This structure is very often used in TV dramas and is one we respond to as it reflects the structure of many traditional stories that are told across times and cultures.

In an analysis of over 1,700 works of fiction in English, Andrew Reagan and colleagues [2016] from the University of Vermont came up with six key story lines (though other studies or practitioners have cited different numbers of story structures over time, from three by William Foster-Harris [1959] to 36 by Georges Polti [1921]). The six structures from the Reagan and colleagues' study are, with examples:

1. Rise-fall (Icarus) Many stories of Hans Christian Andersen

2. Fall-rise-fall (Oedipus Rex) Many Old Testament stories.

3. Fall-rise (Man in a hole) The Magic of Oz stories.

4. Steady fall (Riches to rags) Romeo and Juliet.

5. Steady rise (Rags to riches) Alice's Adventures Underground.

6. Rise-fall-rise: (Cinderella) A Christmas Carol.

The researchers also found that the most popular stories followed the Rise-Fall of Freytag's pyramid.

Metaphors

Metaphors are a very powerful tool from traditional storytelling that can both make a complex idea more understandable, and can be used to bring an unfamiliar idea into one more acceptable. A good example is the metaphor for the way positive ions bond to negative ions, as being like lovers in an ardent embrace who, if separated, rush back together with astonishing speed [Shaha, 2008]. 
But getting just the right metaphor is important. A study by psychologists Stephen Flusberg, Paul Thibodeau and Teenie Matlock [2017] found that the metaphors used to describe global warming can influence people's beliefs and actions. They asked 3,000 Americans to read a short online news article about climate change - but with two slightly different versions of the story. In one, the metaphor 'war against climate change' was used, and the other the 'race against climate change' was used.

Those who read about the 'war' against climate change were more likely to then agree with scientific evidence showing it is real and human-caused, compared to those who read about the 'race' to solve climate change.

The researchers suggested that war metaphors remind us of other war-related concepts, like death and struggle, which remind us of the negative feelings and consequences of being defeated in war, and the importance of being victorious.

The culture of story telling
But there is clearly a lot more to it than just having a good story with a good structure, and a good metaphor, because we know that even the best told story of climate change will not convince everyone to believe the clear evidence for human-induced climate change. The same way that a well-told story about genetic engineering will not convince everyone to subscribe to the benefits of gene technology.

To understand how stories work, and fail to work, in practice we need to also look at the role of stories culturally.

The practice of storytelling is many, many thousands of years old and has evolved in different cultures and countries - but still has striking similarities, as explored by Carl Gustav Jung [1959] who argued that there are certain story types and symbols that are uniform across global cultures, and invoke powerful responses from us.

Old Testament stories like Noah and the flood might have little scientific basis to support them, but they have proved a powerful underpinning for reinforcing Christian and Jewish beliefs for many hundreds of years, the same way that stories from the Mahabharata or the Ramayana have underpinned Hindu beliefs. Other European Epic heroes like Odysseus, Väinämöinen, Finn, Saint George and Siegfried - or the Monkey King in Asia and Anansi in West Africa - have been said to reinforce cultural values.

The traditional impact of these stories and heroes has faded in the modern world, often being replaced by more contemporary heroes - who reflect different spiritual and cultural values. Most traditional heroic epics are about strong male heroes overcoming setbacks to finally conquer an obstacle - which is a narrative that is not so strongly supported in society as it had once been. Stories of women and cunning winning over might, may well resonate better with many in modern societies (something well played on by the makers of blockbuster super hero films) which implies the power of stories is not in shaping us to the values within the story, but how well they can tap into the values that we intrinsically hold already. 
That is important to know, and explains why the best structure and metaphors and empathy-triggers are not going to work on everybody.

And let's not forget that while we might have fashioned a good story — others might be busy fashioning competing stories.

\section{Competing} narratives

It should come as no surprise to know that for many contentious issues there are many strongly competing narratives being told, that work hard to influence us in one direction or another. One example of competing narratives is when U.S.

President Donald Trump publicly worked up support for the U.S. to pull out of the 2015 Paris Agreement on climate change reduction. The Paris Agreement had set a common goal for mitigating climate change - which he framed as harming American workers, who would lose their jobs as a result of it.

In his story, he was the Hero, the climate change agreement became the Villain, and U.S. workers were the Victims [Munshi and Kurian, 2018].

After he had made this statement, however, many European leaders responded with their own narratives, in which they framed President Trump as the Villain, the planet and climate change scientists and other countries as the Victims, and the rest of the world's unity as the Hero.

Countering narratives with other narratives is an effective strategy, but as Marty Kaplan [2013] of the University of Southern California says, "You know the expression 'don't bring a knife to a gun fight'? I submit, 'Don't bring a data set to a food fight'."

But we should all know this already. Stories are about emotions over facts, and people respond much better to emotions than facts - and will openly reject facts if they do not align with their values. As we should know that there are often competing narratives that exist, and different stories or framings from different interest groups battle to define how we might understand a technology - as beneficial, or risk, or well-regulated and so on [Macnaghten, Davies and Kearnes, 2015].

Biologist Andrew Thaler [2017] addresses the importance of emotions over facts in reaching the general public in what he calls, 'When I talk about climate change, I don't talk about science.' Instead, he says, he talks about things that are important to his audiences, such as fishing, flooding, farming, faith and the future. Stories about these things can then form an entry point to deeper discussions about climate change.

He says, "Data is the map, storytelling is the journey."

The importance of failure in stories
And we should not ignore the importance of failure in stories. Tracey Segarra [2018], who is on the Board of Directors of the U.S. National Storytelling Network, says that for a story to work well it has to have a few essential ingredients: 
- Make sure it is your story, not someone else's,

- A story needs tension and stakes - what you stand to gain or lose,

- Stories have to be authentic to beat people's built-in bullshit detectors,

- It is our failures more than our successes that humanize us and encourage people to empathize with us.

You can check out the personal stories of science on sites like Storycollider.org to see some of these in action, but that last point of Segarra's is very important, as nearly all epic story structures are built around the notion of overcoming failure. You can see it in the traditional hero's journey structure that was used in the first Star Wars film (as well as other blockbusters including Finding Nemo, the Wizard of $\mathrm{Oz}$, the Matrix and many, many more). It has a few variations, but there are basically about a dozen steps, that take a central character from a normalized world (the Shire, Tatooine, Neo's workplace etc), through a series of stages that sees them falter, learn and then eventually overcome their obstacles or nemesis and return home a changed person.

It's a good structure to know because it's not just a very powerful subconscious structure, but neatly tells the story of most scientists in their careers as well, and can therefore be used with great effect to tell a science story. (Did you see what I did there? ABT!).

But most of the stories that we tell of science go out of their way to delete any mention of failure. Publication is also almost only about successes. Media releases are almost uniformly about successes. And grant seeking is ALL about successes.

Even the word 'failure' is avoided - and terms like 'null result', 'dead-end', 'lack of outcome' and 'unexpected result', are used. Because we do not often tell the stories of the processes of science and the failures that come with them, when a scientist says, 'just trust us,' - why should we expect there to be any empathetic foundation for that if it has not been built?

The other key point to understand from the hero's journey is the end state of change, or transformation - which is the key objective of science story telling - to affect some sort of change, be it attitudinal or behavioural.

There are no short cuts. You only get there if you follow the stages of the story.

What does it all mean?
So what can we conclude from all the things we can learn from modern research into how stories work on us, as well as what we can learn from the longer traditions of cultural storytelling, and apply these to the stories we tell of science?

Well, we should understand that the tools of storytelling are important — but we need to look at them as more than style tricks of framing and metaphor, and find ways to ensure our stories more deeply resonate at a human level through mirroring people's values.

And we need to accept that there is no one-size-fits-all approach for motivating people to believe in the science of things like climate change, and we need to tell 
different stories that best align with different people's values. Sometimes we need to tell stories about the damage being done to the planet, and sometimes we need to talk about the damage being done to one's personal property, and sometimes we need to just remind people how wonderful the Earth is and what it is we need to do to protect it.

Maura Sweeney [2017], writing in the Huffington Post, said:

\begin{abstract}
At their best, good stories point to the greatness in us all and move us toward a happier future. They propel us to become innovators, inventors, creative artists, business leaders, statesmen and cultural change-makers. Individually and collectively, stories point us towards a more prosperous, harmonious and successful human race while reminding us to play our part in the process.
\end{abstract}

Not everyone is as convinced, it should be pointed out, such as Yarden Katz [2013], who in an issue of Nature Methods in which the editors asked if scientists should or should not tell stories, cautioned that over-emphasis on telling a good story could risk compromising good science.

It's a fair point - and we need to ensure we don't get carried away and become the Corporate Storytellers I referred to earlier. Neither should we try and roll all the research into storytelling and narrative together and believe it will give us a single magic formula for success - without proper testing of what we have put together on a sample of the target audience we are seeking to reach.

Our struggle to better tell the stories of science is a continuing quest, but as we get better at telling those stories we should better overcome the obstacles about us and better connect with our audiences. And hopefully find ways to all live more happily ever after.

Rise - Fall — Rise.

References

Dahlstrom, M. F. (2014). 'Using narratives and storytelling to communicate science with nonexpert audiences'. Proceedings of the National Academy of Sciences 111 (Supplement 4), pp. 13614-13620.

https://doi.org/10.1073/pnas.1320645111.

Downs, J. S. (2014). ‘Prescriptive scientific narratives for communicating usable science'. Proceedings of the National Academy of Sciences 111 (Supplement 4), pp. 13627-13633. https://doi.org/10.1073/pnas.1317502111.

Flusberg, S. J., Matlock, T. and Thibodeau, P. H. (2017). 'Metaphors for the War (or Race) against Climate Change'. Environmental Communication 11 (6), pp. 769-783. https://doi.org/10.1080/17524032.2017.1289111.

Foster-Harris, W. (1959). The basic patterns of plot. Norman, OK, U.S.A.: University of Oklahoma Press.

Graesser, A. C., Hauft-Smith, K., Cohen, A. D. and Pyles, L. D. (1980). 'Advanced outlines, familiarity and text genre on retention of prose'. The Journal of Experimental Education 48 (4), pp. 281-290. https://doi.org/10.1080/00220973.1980.11011745. 
Green, M. C. and Brock, T. C. (2000). 'The role of transportation in the persuasiveness of public narratives'. Journal of Personality and Social Psychology 79 (5), pp. 701-721. https://doi .org/10.1037/0022-3514.79.5.701.

Halverson, J. R. (8th December 2011). Why story is not narrative, centre for strategic communications.

URL: https://csc.asu.edu/2011/12/08/why-story-is-not-narrative/ (visited on 6th March 2019).

Immordino-Yang, M. H. (2011). 'Me, my "self" and you: neuropsychological relations between social emotion, self-awareness and morality'. Emotion Review 3 (3), pp. 313-315. https://doi.org/10.1177/1754073911402391.

Jung, C. G. (1959). Archetypes and the collective unconscious. Bollingen.

Kaplan, M. (2013). 'The narratives of science communication'. In: Proceedings of Science of Science Communication II (National Academy of Sciences, Washington, DC, U.S.A. 23rd-25th September 2013).

Katz, Y. (2013). 'Against storytelling of scientific results'. Nature Methods 10 (11), pp. 1045-1045. https://doi.org/10.1038/nmeth.2699.

Macnaghten, P., Davies, S. R. and Kearnes, M. (2015). 'Understanding public responses to emerging technologies: a narrative approach'. Journal of Environmental Policy \& Planning, pp. 1-19. https://doi.org/10.1080/1523908x.2015.1053110.

Munshi, D. and Kurian, P. (2018). 'Framing futures through fiction and folklore: weaving past and prospective narratives of public understanding of climate science'. In: Public Communication of Science and Technology Conference (University of Otago, Dunedin, New Zealand).

National Academies of Sciences, Engineering and Medicine (2017). Communicating science effectively: a research agenda. URL: https://www .nap.edu/read/23674/chapter/1.

Niemand, A. (7th May 2018). 'How to tell stories about complex issues'. Stanford Social Innovation Review. URL: https://ssir.org/articles/entry/how_to_tell _stories_about_complex_issues (visited on 6th March 2019).

Olson, R. (2015). Houston, we have a narrative. Chicago, IL, U.S.A.: University of Chicago Press.

Polti, G. (1921). The thirty-six dramatic situations. Franklin, OH, U.S.A.: James Knapp Reeve.

Reagan, A. J., Mitchell, L., Kiley, D., Danforth, C. M. and Dodds, P. S. (2016). 'The emotional arcs of stories are dominated by six basic shapes'. EPJ Data Science 5 (1). https://doi .org/10.1140/epjds/s13688-016-0093-1.

Sanford, A. J. and Emmott, C. (2013). Mind, brain and narrative. Cambridge, U.K.: Cambridge University Press.

Segarra, T. (2018). 'The power of story'. Change Agent (Winter). URL: https://www. comnetwork.org/insights/the-power-of-story/ (visited on 6th March 2019).

Shaha, A. (30th March 2008). 'Credit where credit is due'. Lablit. URL: http://www. lablit. com/article/365 (visited on 6th March 2019).

Stephens, G. J., Silbert, L. J. and Hasson, U. (2010). 'Speaker-listener neural coupling underlies successful communication'. Proceedings of the National Academy of Sciences 107 (32), pp. 14425-14430. https://doi.org/10.1073/pnas.1008662107.

Sweeney, M. (12th December 2017). 'The power of stories'. Huffington Post. URL: https://www. huffingtonpost.com/entry/the-power-of-stories_us_5a 302e74e4b0b73dde46a7e6 (visited on 6th March 2019). 
Thaler, A. D. (3rd January 2017). 'When I talk about climate change I don't talk about science'. Southern Fried Science. URL: http://www. southernfriedscience .com/when-i-talk-about-climate-change-i-dont-talk-about-science/ (visited on 6th March 2019).

Waxler, R. and Trounstine, J., eds. (1999). Changing lives through literature. Notre Dame, IN, U.S.A.: University of Notre Dame Press.

Author

Craig Cormick is an award-winning novelist and past President of the Australian Science Communicators. He is author of the upcoming book Communicatology: the Science of Science Communication (CSIRO Publications).

E-mail: craig.cormick@thinkoutsidethe.com.au.

How to cite

Cormick, C. (2019). 'Who doesn't love a good story? - What neuroscience tells about how we respond to narratives'. JCOM 18 (05), Y01.

https://doi.org/10.22323/2.18050401. 